УДК 78.03/.09

Вероніка Юріївна Дорофеєва, кандидат мистецтвознавства, доцент Київського національного університету культури і мистецтв odma_n@ukr.net

\title{
ФОРМУВАННЯ СУЧАСНОГО МУЗИЧНОГО СТИЛЬОВОГО ПРОСТОРУ НА ПРИКЛАДІ ТВОРЧОСТІ УКРАЇНСЬКИХ КОМПОЗИТОРІВ
}

Мета статті - окреслити основні стилістичні тенденції, які представлені в українському академічному музичному просторі. Досягнення цієї мети полягає у виокремленні творчих підходів різних українських композиторських шкіл для визначення їх конкретної взаємодії в соціальному та культурному плані. Методологія дослідження. Для вивчення особливостей сучасної стильової палітри в просторі академічної музики України використовуються аналітичний метод та метод синтезу. $\mathbf{H a -}$ укова новизна. Творчим методом сучасних українських авторів є вільне оперування досягненнями стильових напрямків минулого і їх поєднання з провідними композиторськими техніками сьогодення. Зростання інтересу до засобів масової інформації, електронної музики є одним з перспективних напрямків культури ХХІ століття. Висновки. Виділяється значна роль неофольклоризму як одного з провідних і визначних напрямків сучасності. Акцентується увага на використанні принципу полістилістики, який призводить до формування метамови. Відзначено виникнення тенденції до відродження традицій, притаманних українському мистецтву, що виявляється в становленні «нового бароко».

Ключові слова: стильовий простір, українські композитори, неофольклоризм, «нове бароко», полістилістика.

Dorofeeva Veronika, Ph.D. in the History of Art, assistant professor of the Kyiv National University of Art and Culture

Formation of modern musical style space on the example of creativity of Ukrainian composers

The purpose of the article is to determine the main stylistic trends that are presented in the Ukrainian academic music space. Achieving this goal consists in isolating the creative approaches of various Ukrainian composer schools to determine their specific interaction in social and cultural terms. The methodology of the research. To study the peculiarities of the modern style palette in the academic music space of Ukraine, an analytical method and a synthesis method are used. Scientific novelty. The creative method of modern Ukrainian authors is the free operation of the achievements of style trends of the past and their combination with the leading compositional techniques of the present. Growing interest in

(С) Дорофеєва В. Ю., 2016 
the media and electronic music is one of the promising areas of the culture of the 21 st century. Conclusions. A significant role is played by neo-folklore as one of the leading and outstanding trends of the present. Attention is focused on the use of the principle of polystylistics, which leads to the formation of a meta-language. The emergence of a tendency to revive the traditions inherent in Ukrainian art, manifested in the formation of the, «neo-baroque».

Keywords: stylistic space, Ukrainian composers, neofolklorism, «neo-baroque», polistylistic.

Дорофеева Вероника Юрьевна, кандидат искусствоведения, доцент Киевского национального университета искусств и культуры

Формирование современного музыкального стилевого пространства на примере творчества украинских композиторов

Цель статьи - определить основные стилистические тенденции, которые представлены в украинском академическом музыкальном пространстве. Достижение этой цели заключается в выделении творческих подходов различных украинских композиторских школ для определения их конкретного взаимодействия в социальном и культурном плане. Методология исследования. Для изучения особенностей современной стилевой палитры в пространстве академической музыки Украины используются аналитический метод и метод синтеза. Научная новизна. Творческим методом современных украинских авторов является свободное оперирование достижениями стилевых направлений прошлого и их сочетание $c$ ведущими композиторскими техниками настоящего. Рост интереса к средствам массовой информации, электронной музыке является одним из перспективных направлений культуры ХХІ века. Выводы. Выделяется значительная роль неофольклоризма как одного из ведущих и выдающихся направлений современности. Акцентируется внимание на использовании принципа полистилистики, который приводит к формированию метаязыка. Отмечено возникновение тенденции к возрождению традиций, присущих украинскому искусству, проявляющихся в становлении «нового барокко».

Ключевые слова: стилевое пространство, украинские композиторы, неофольклоризм, «новое барокко», полистилистика.

Актуальність теми дослідження. Український мистецький музичний простір представлений значною кількістю композиторів. Так, кожного року виникає ряд музичних проектів, що сприяє відкриттю нових імен, в той час як плідно продовжують працювати класики національної композиторської школи. Зі зміною поколінь та плином часу поступово відбувається зміна стильового забарвлення авторської творчості. Дослідження специфіки розвитку академічної гілки музичної культури України є актуальним та важливим завданням, 
хоча й досить складним, адже важко оцінити значення подій, які ще не пройшли перевірки часом. Проте загальновідомо, що в історії музичного мистецтва залишились згадки про композиторів та їх твори саме завдяки високій оцінці їх сучасників, що зумовлює доцільність звернення до сучасного стильового простору.

Аналіз досліджень і публікацій. Специфіка сучасної стильової палітри представлена в роботах Г. Ніколаї та О. Сєрової. Аналіз, представлений в праці С. Садовенко, спрямований на дослідження проявів неофольклоризму в творчості українських композиторів. Філософсько-культурологічне обгрунтування стильової динаміки в межах сучасної української музичної практики здійснюється в роботах I. Легенького та О. Опанасюка. Питання, пов’язані з електронною музикою та іï медійною формою існування, представлені в наукових розробках А. Загайкевич та М. Черкашиної-Губаренко.

Метою статті $є$ окреслення основних стильових напрямків, які представлені в сучасному українському академічному музичному просторі. Досягнення поставленої мети передбачає виокремлення творчих підходів представників різних українських композиторських шкіл задля виявлення специфіки їх взаємодії в соціокультурному вимірі.

Виклад основного матеріалу. Аналіз сучасного музичного українського простору є досить складним завданням, адже кожен композитор прагне віднайти власний стиль, принципи оркестрування, звертається до різних жанрів. Проте можна виділити декілька тенденцій, які характерні для більшості авторів. Насамперед варто згадати, що кінець XX століття проходив під гаслами постмодернізму, для якого притаманне звернення до всіх попередніх стильових напрямків, їх вільного поєднання, змішування, цитування. Основою постмодерного погляду на життя є іронія, яка проявляється у відсутності певних ідеологічних настанов, все піддається сумніву. Проте на початку XXI століття поступово відбувається зменшення іронічності на користь ліричності та щирості. Г. Ніколаї зазначає, що визначальними рисами української музики стали відкритість до світу, «діалогічність» у стосунках із природним і людським довкіллям, мрійливість та дух гіперболізації. Музикознавець згадує наступні риси композиторської творчості сьогодення: «Сучасні вітчизняні композитори прагнуть опрацьовувати на національному грунті стилі попередніх епох, застосовуючи як барокові, класичні, романтичні, так і яскраво-індивідуалізовані елементи у їх незвичній, оригінальній постмодерній взаємодії. Спостерігається органічне поєднання національно-етніч- 
них фольклорних джерел з надбаннями східних та західних культур минулого і сучасності. Відбувається відродження інтересу митців до прадавніх цінностей народу - передусім до релігійних ідеалів як найвищого символу духовності» [3, 131].

Взаємозв’язок композиторської творчості та фольклорного начала дійсно був і залишається одним з провідних принципів, які притаманні українській національній музиці. Риси «неофольклоризму» можна віднайти у творчості багатьох класиків сучасної музичної культури - Л. Грабовського, Л. Дичко, М. Скорика, С. Станковича. «Сьогодні неофольклорні тенденції і близькі до неофольклоризму стилі залишаються модусом оновлення художніх засобів, принципів музичного мислення і тональної організації у творчості композиторів України. Саме неофольклоризм є символічним центром всієї української музичної культури. «Осучаснення» архаїки продовжує знаходити відображення в активному проникненні неофольклоризму в сучасну композиторську творчість не тільки української, а й світової музичної культури» [5, 176-177].

Неофольклорна течія хоча й є в певному сенсі магістральною для українського композиторського мислення, є ряд інших напрямків, представлених в сучасній музиці. Риси неокласицизму притаманні певним творам В. Сильвестрова. В музичній практиці значно зростає тяжіння до неоромантизму, ліричне начало починає змінювати скептичне світобачення. Г. Ніколаї влучно характеризує музичні особливості фортепіанної музики наприкінці XX століття, що у повній мірі може бути застосоване до інших жанрів композиторської творчості: «Починаючи з 80-90-х років XX століття характерними для української фортепіанної музики стають: інтертекстуальність як одна з можливостей нового «прочитання» традицій; «нова фольклорна хвиля», де відбувається синтез архаїчних фольклорних мелодій, народно-танцювальних ритмів, характерних українських інтонацій в умовах сучасного композиторського письма; «гра з традицією» на рівні часових епох, стилів, жанрів, музичних форм; полістилізм як метамова, що об'єднує всі культурні надбання минулого й сучасного, а також постійне прямування до універсальних категорій. Музичний полістилізм не порушує індивідуального стилю композитора, але стає певною універсальною мовою, універсальним стилем, «метастилем», який знімає суперечності та об'єднує за своєю суттю художньо-світоглядні традиції різних епох і культур, що їх віддзеркалюють музичні стилі» [3, 131]. Полістилістика залишається одним з провідних прин- 
ципів, який характерний для мистецтва постмодернізму та виступає своєрідним рушієм до творчої переробки досягнень минулих століть.

Досить нетрадиційним для музикознавства, проте доцільним, на нашу думку, є підхід до історії української музики, запропонований в дослідженнях О. Опанасюка. Так автор виділяє чотири основні періоди iї розвитку: інтенціонально-смисловий етап (кінець XIX - початок XX століття), інтенціонально-ідентичний етап (середина XX століття), інтенціонально-динамічний етап (1970-1990-ті роки) та інтенціонально-функційний етап (кінець XX - початок XXI століття). Для першого періоду притаманний «розвиток ретроспективних, інтроспективних, компілятивних і деструктивних форм художнього вираження» $[4,213]$, в другий період розвиваються пізньоромантичні та реалістичні традиції, в третьому періоді відбувається формування сильної композиторської школи, коли поширення набувають такі стильові напрямки, як «неоромантизм», «неотрадиціоналізм», а також розповсюдженим принципом є полістилізм. Влучним є визначення полістилізму, яке наводить I. Легенький: «Полістилізм є тотальноеклектичною реальністю або середовищем, у якому можна визначити більш-менш структурні або автентичні осі алюзій і цитувань у комунікативному просторі алеаторики та експресивному багатоголоссі сонорики. Утім ми бачимо потреби створення відкритого розчиненого простору, який орієнтований на музичну комунікацію» [2, 76].

Найбільш цікавим для даного дослідження є останній період -інтенціонально-функційний етап, коли важко виявити один певний стильовий напрямок. О. Опанасюк зазначає, що для української композиторської школи притаманне стильове різноманіття та стильовий плюралізм. «Можливо, саме цей факт ініціював появу терміна «мішаний стиль», який, однак, не сприяє проясненню стильової ситуації в сучасному мистецтві» $[4,216]$. Якщо виходити з даної концепції, то абсолютно вірним буде твердження про те, що в сучасній українській академічній музиці представлені фактично всі стильові напрямки, які існували до цього часу.

Можна виокремити дві сучасні смислові домінанти, пов'язані 3 емоційним забарвленням творів. Музикознавець С. Садовенко у своєму дослідженні згадує образні сфери, які тяжіють до емоційної нейтральності і бажання «досягти межі тиші» та музичні стогони, «плачі». Образність першої групи притаманна таким композиторам, як А. Загайкевич та В. Польова. До другої ж відносяться ряд творів I. Щербакова та В. Зубицького. 
Одним з напрямків, який здобув значного розвитку в українській музиці, є мінімалізм. У другій половині XX століття вплив мінімалізму позначився на творчості Л. Грабовського, В. Сильвестрова, О. Щетинського, а на початку XXI століття його прояви присутні в творах 3. Алмаші, О. Безбородька, В. Губи, С. Зажитька, О. Козаренка, В. Польової, О. Сєрової, О. Шимка. Варто зазначити, що насамперед йде мова про застосування техніки мінімалізму, а не повне відтворення стилю. О. Сєрова вказує на те, що більшість авторів поєднують іiі зі зверненням до фольклору та власними творчими методами. «Специфікою творів українських композиторів, творчість яких кореспондується з мінімалізмом, стали спрямованість на концептуальність, сакральність, естетичні та мистецькі ідеали минулого, фольклор, що сприяє усвідомленню безперервності зв'язку часів, а також інтуїтивна орієнтованість на одухотвореність принципів «повернення до гармонії», рівноваги традицій і новаційності, відновлення й оновлення національного» $[6,55]$.

Ця ж ідея підкреслюється в дослідженнях інших мистецтвознавців. Застосування широкого стильового спектра в рамках діяльності одного композитора може передати його творчий задум, а також бути ознакою його приналежності до українського соціокультурного типу буття. І. Легенький вказує: «За фольклоризмом ховається образ світу, який визначається в урбанізованому середовищі архітектурного простору як «музичні фрески»... Фрески в музиці кінця XX - початку XXI століття - це сучасні технології, позбавлені музичної матерії, фрескового матеріалу. Тут немає каменю, немає піску, є лише звук, що звучить і не звучить» $[2,78]$.

Варто відзначити зростання ролі композиторських технік, які були мало представлені у вітчизняній традиції. Насамперед це стосується розвитку сфери комп'ютерного синтезу звуку, що все більше поширюється серед композиторів. Одним з провідних апологетів електронної музики, поєднання звучання «живих» інструментів та їх синтезу та обробки в спеціальних комп'ютерних програмах є А. Загайкевич. В її творчому доробку не лише електронна музика, крім неї $€$ також симфонічна та камерна музика, опера, музика до кінострічок О. Саніна «Мамай» та «Поводир». А. Загайкевич зазначає: «Електронна музика від самого свого зародження оперує принципово інакшою акустичною матерією, пов'язаною з особливою художньою реальністю - світом «синтезованого» мистецтва з притаманним йому колом технологічних концепцій. Утворена «ad marginum» на перехресті тя- 
жінь двох художніх систем сучасного академічного музичного мистецтва та синтетичного медійного мистецтва, електронна музика поступово утворила самодостатню галузь творчості, де постійних метаморфоз зазнають такі фундаментальні для музичної теорії поняття, як «музична творчість», «музичний твір», «музична форма», «музичний інструмент», «тембр», «фактура» $[1,39]$.

Формування стильового простору в сучасній композиторській школі відбувається в тому числі за рахунок того соціокультурного обрамлення, в якому виростають майбутні митці. Важливим компонентом, який впливає на творчу постать, є культурні проекти та ініціативи. Зауважимо, що внаслідок активної фестивальної практики в українському мистецькому просторі можна спостерігати появу своєрідного «соціального замовлення» на певні жанри для визначених інструментів або виконавського колективу, яке відбувається за рахунок проведення в рамках Міжнародного форуму «Музики молодих» (та подібних фестивалів) різноманітних проектів, на зразок: «Solo flute project», «Проект етносучасність», «The solo piano project» та інші. М. Черкашина-Губаренко вказує на те, що кожен фестиваль тримається на тісній взаємодії багатьох чинників: «творчого, організаційного і фінансово-економічного, до яких додається і певний часо-простір, розрахований на розвинутий туристичний бізнес. Творче обличчя фестивалю формує яскрава особистість і суб'єктивні смаки лідера, який $є$ авторитетом і у професійних колах, і серед можновладців, від яких залежить фінансова і громадська підтримка проекту. Однак так само важливою є і постать адміністративного керівника, - директоpa, інтенданта, менеджера, який несе відповідальність за всю організаційну частину і забезпечує творчому лідеру можливості здійснення його художньої програми» $[7,80]$. Тобто формування стильового простору залежать також від керівників соціальних, креативних структур, результати діяльності яких становлять соціокультурне тло сьогодення.

Досить важко віднайти єдину думку стосовно стильового визначення тих тенденцій, які присутні в композиторській творчості. І. Легенький вказує на те, що сучасну музичну культуру можна визначити як «нове бароко»: «Символічна метафорика відсувається, хоча вона $€$ бажаною й потребує свого носія, протагоніста драматизованого середовища. Так, можливо стверджувати, що всі ефекти полістилістики поступово переходять у ту надпрограму динамічного, відкритого середовища, що в музиці характеризує добу «нового бароко» $\mathrm{XX}$ ст.» $[2,76]$. Прикладами творів, що можуть бути названі «нове бароко», $€$ 
«Ектенія заупокійна» $\mathrm{C}$. Станковича, «У Києві зорі» та «І нарекоша ім'я Київ» Л. Дичко.

Висновки. Сучасний стильовий простір української академічної музики демонструє кореляцію між традицією та новаторством. Одною з провідних ознак творчості більшості композиторів є вільне оперування здобутками попередніх століть. Проявами полістилістики є творче переосмислення доби бароко, класицизму, романтизму з виходом на принципово новий рівень, що характеризується появою метамови, а також стилів «нове бароко», неоромантизм. Магістральною рисою стильового простору України стає звернення до неофольклоризму, що проявляється у своєрідному ладоінтонаційному комплексі, який при цьому може розроблятися за допомогою методів, притаманних мінімалізму. Зростання інтересу до медійної, електронної музики, вбачається одним з перспективних напрямків розвитку культури XXI століття.

\section{СПИСОК ЛІТЕРАТУРИ}

1. Загайкевич А. Українська електронна музика: практика дослідження. Музика в інформаційному суспільстві. Київ: Нац. муз. акад. ім. П. І. Чайковського, 2008. Вип. 76. С. 39-62.

2. Легенький I. Ю. Феномен плюралізації нонконформного руху в полістилістиці музичної культури України кінця XX - початку XXI століття. Актуальні проблеми філософії та соціології: науково-практичний журнал. Одеca, 2016. № 11. C.76-78.

3. Ніколаї Г. Українська фортепіанна музика як феномен культури XX століття. Ars inter Culturas. 2010. № 1. С.121-132.

4. Опанасюк О. П. Стильова динаміка та особливості розвитку української музики XX - початку XXI століть. Актуальні проблеми історії, теорії та практики художньої культури. Київ: Міленіум, 2011. Вип. 26. С. 209-219.

5. Садовенко С. М. Неофольклоризм у контексті музичної культури України другої половини XX - початку XXI століття. Культура і сучасність: альманах. Київ: Міленіум, 2010. № 2. С. 173-177.

6. Серова О. Ю. Стильова валентність мінімалізму в українському музичному просторі. Мистецтвознавчі записки. Київ: Міленіум, 2014. Вип. 26. C. $48-56$.

7. Черкашина-Губаренко М. Українська музика у сучасному медіа-просторі: фрагменти і коментарі. Мистецтвознавство України. Київ: Музична Україна, 2009. Вип. 10. С. 78 -82. 


\section{REFERENCES}

1. Zahaykevych A. (2008) Ukrainian electronic music: research practice. Music in the Information Society. Kyiv: Nats. muz. akad. im. P. I. Chaykovskoho, 76. 39-62 [in Ukrainian].

2. Lehenkyy I. Yu. (2016) The phenomenon of pluralization of the nonconformal movement in the polystylistics of musical culture of Ukraine in the late XX early XXI centuries. Actual problems of philosophy and sociology: scientific and practical journal. 11. 76-78 [in Ukrainian].

3. Nikolayi H. (2010) Ukrainian piano music as a phenomenon of culture of the twentieth century. Ars inter Culturas. 1. 121-132 [in Ukrainian].

4. Opanasyuk O. P. (2011) Stylistic dynamics and peculiarities of the development of Ukrainian music from the XXth to the beginning of the XXI centuries. Actual problems of history, theory and practice of artistic culture. Kyiv.: Milenium. 26. 209-219 [in Ukrainian].

5. Sadovenko S. M. (2010) Neo-folklorism in the context of musical culture of Ukraine in the second half of the 20th - the beginning of the 21st century. Culture and modernity: an almanac. Kyiv: Milenium. 2.173-177 [in Ukrainian].

6. Syerova O. Yu. (2014) Stylistic valency of minimalism in the Ukrainian musical space. Art scenes notes. Kyiv.: Milenium. 26. 48-56 [in Ukrainian].

7. Cherkashyna-Hubarenko M. (2009) Ukrainian music in modern media space: fragments and comments. Art studies of Ukraine. 10. 78-82 [in Ukrainian].

Стаття надійщла до редакції 07.06.2016

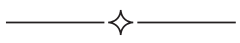

УДК 929:130.3/784+159.923

Анна Вікторівна Палійчук, викладач кафедри естрадного співу

факультету музичного мистецтва

Київської муніципальної академії естрадного та циркового мистецтва konuschenko65@gmail.com

\section{НОЕМАТИЧНІ ПЕРЕДУМОВИ СТИЛЬОВОГО МИСЛЕННЯ В. ІВАСЮКА}

Мета роботи полягає в розробиі ноематичного підходу до музичного стилю та особливостей стильового мислення В. Івасюка. Методологія дослідження визначається феноменологічним, зокрема ноологічного прямування, методом та мистецтвознавчими естетико-стильовим й семіологічним підходами. Наукова новизна зумовлюється розвитком ноематичного напряму вивчення музичного стилю, визначенням своєрідності

(c) Палійчук А. В., 2016 